\title{
КУАЬТУРОАОГІя
}

https://doi.org/10.31516/2410-5325.073.01*

УДК 316.73:005.11:008:339.94](045)

Kharkiv State Academy of Culture, Kharkiv, Ukraine

\section{MEDIATION OF CULTURE DIALOGUE IN INTERNATIONAL CIVILIZATIONAL COOPERATION PROCESSES IN THE CONTEXT OF GLOBALIZATION}

V. Sheiko. Mediation of culture dialogue in international civilizational cooperation processes in the context of globalization

The processes of mediation of intercultural dialogue during the establishment of international cooperation in the context of globalization are analyzed. The issues of genesis and formation of dialogue and its formation in the field of culture in the age of civilizational globalization are considered. At the same time, the role of international organizations in the development of intercultural dialogue is shown. It is demonstrated that the sustainable development of modern civilization mainly depends on the dialogue of cultures as a mediator in the process of international cooperation establishment.

Keywords: cultures dialogue mediation, civilization, globalization, culture, international cooperation, UNESCO, sustainable development of the world.

B. М. Шейко. Медіація діалогу культур у процесах міжнародної цивілізаційної співпраці в умовах глобалізаціі

Мета цієї статті - висвітлити посередницьку роль міжкультурного діалогу в процесах міжнародного цивілізаційного співробітництва в контексті глобалізації. Такий науковий інтелект визначається актуальністю обраної проблеми. Адже саме завдяки посередницькій ролі діалогу культур світовій спільноті вдається багато в чому підтримувати мир на земній кулі та налагоджувати міжнародне співробітництво в суворих умовах цивілізаційної глобалізації. Крім того, це питання ще маловивчене.

Методологічною основою цього дослідження є культурологічні методи та принципи аналізу посередницької ролі міжкультурного діалогу у встановленні міжнародного співробітництва в контексті цивілізаційної глобалізації.

Результатом наукових досліджень є детальний культурологічний аналіз проблеми посередницької ролі міжкультурного діалогу в процесі налагодження міжнародного співробітництва та підтримання миру на Землі в умовах цивілізаційної глобалізації.
Наукова актуальність статті полягає в тому, що за допомогою культурологічної методології вдалося виокремити посередницьку роль міжкультурного діалогу в процесах міжнародного цивілізаційного співробітництва в контексті глобалізації, що дозволяє світовій спільноті підтримувати мир на планеті.

Практичне значення статті полягає в тому, що 1 11 результати можуть бути корисними під час подальших досліджень з обраних тем. Водночас вони можуть стати матеріалом у процесі підготовки науково-методичної документації до курсів культурології.

Ключові слова: посереднищтво діалогу культур, цивілізація, глобалізачія, культура, міжнародне співробітництво, ЮНЕСКО, сталий розвиток свіmy.

Background. Analyzing the available literature, which deals with the selected topic or related to it, it should be noted that it is not numerous. For example, V. Yevtukh (2009) analyzes the content of intercultural dialogue as an effective construct of the integrated development of polyethnic societies. V. M. Mezhuiev (2011) studies dialogue as a means of intercultural communication in the modern world, and L. S. Dynikova (2014) deals with dialogue as a means of cultural existence. A. Yu. Arefieva (2019), V. M. Shcherbyna (2011), M. O. Chernets (2015), and O. Mitkina (2013) consider dialogue as a paradigm of culture, as a cultural mission, as a mediation of intercultural dialogue. Some works highlight aspects of cultural clash and the function of dialogue in this process (Vysotskyi, 2015), the role of dialogue in shaping the dialogic nature of Ukrainian culture (Stepyko, 2014), or the role of European intercultural dialogue in the context of forming a single cultural space (Kornienko, 2010).

However, some studies also show mediation and its role in culture and intercultural dialogue (Rohochaia, 2018; Sinitsyna, 2017; Yasynovskyi, 2014). The article by A. Kozak (2013), for

* This work is licensed under a Creative Commons Attribution-NonCommercial-ShareAlike 4.0 International License. 
example, examines intercultural communication in the context of intercultural dialogue, and M. Herashchenko (Herashchenko, 2018) attempted to address the genesis and main trends in mediation in a cross-cultural environment, outlining possible ways to implement it in Ukraine.

Thus, the role of intercultural dialogue as a mediating factor in the processes of international civilizational cooperation in the context of globalization is still a poorly researched and relevant issue.

Results and discussion. That is why in the modern conditions of globalization and civilization evolution the merit of sustainable development of the world community is the dialogue of cultures. Therefore, it is time for researchers to analyze the origins and mediation processes of intercultural dialogue. It can be said with some confidence that the history of civilization is a dialogue of people, nations, cultures. After all, dialogue is a kind of mediator of international relations, it is a condition for mutual understanding of people, nations, and cultures. The interaction of cultures is dominant in the development of interethnic and interethnic relations. Conversely, when there are interethnic tensions and interethnic conflicts in society, the mediation of dialogue between cultures is complicated, and the interaction of cultures can take place only to a limited extent, in the field of interethnic tensions of these peoples, carriers of these cultures.

The history of human culture, with a certain degree of conditionality, can be interpreted as a long process of realizing the relationship "wethey". Chronologically, the first intertribal human communication program in the field of culture took the form of a kind of rejection. Over time, tribal isolationism, strange as it may sound, played a mediating consolidating role in the formation of the original collective. After all, in those ancient times, the exclusion of a foreigner, non-recognition of a representative of another tribe was typical of the worldview of the ancient Greeks, who "being acutely aware of the rights of citizens, could not feel human rights" (Averintsev, 1989, p. 10).

The analysis of the civilizational processes of international cultural cooperation, as it turned out, was much more complicated than it seemed at first glance. It was believed that there is an elementary "flow" of the achievements of highly developed culture into the less developed one. And this seemed to provide a basis for conclusions about the interaction of cultures as a source of progress.

The mediating role of intercultural dialogue usually involves the active interaction of equal subjects. Such interaction of cultures and civilizations should, logically, contribute to the enrichment of different cultures. In addition, historical experience has shown that intercultural dialogue has increasingly acted as a mediator of reconciliation, enabling the prevention of wars and conflicts. This factor helped to relieve tensions, create an atmosphere of trust and mutual respect. Over time, the dialogue of cultures as a social phenomenon became more relevant. The theory and practice of dialogue have deep civilizational and historical roots. Ancient texts of Indian culture, for example, reasonably interpret the ideas of unity of cultures and peoples, macro-and microcosm, awareness of the power of human beauty, and contain reflections on society and the universe.

We know the history of humanitarian thought in the perspective of awareness of the ethnocultural diversity of mankind originates in the philosophy of ancient Greece. The essence of the dialogue was studied by the ancient Greek philosopherssophists - Socrates, Plato, Aristotle, philosophers of the Hellenistic era. Significantly, the history of dialogue in their works was based on the civilizational and spiritual foundations of culture. At the same time, they recognized pluralism and equality of opinion, universal principles, freedoms, and social values as dominant. As we know, the spiritual culture of civilizations developed in an inseparable connection with religion. That is why the dialogue of cultures "is not just the interaction of peoples, but also their deep mystical connection, rooted in religion" (Nikitin, 2000, p. 26). Thus, the dialogue of cultures is closely linked to the dialogue of religions. The Apostle Paul emphasized: "You must think differently so that you may be the most skillful" (Saiko, 1990, p. 10). On the other hand, keep in mind that one-dimensional rationalism of thought can lead to a simplistic or erroneous conclusion. As a verbal form of relationship, mediation of intercultural dialogue presupposes a certain commonality of space and time, empathy, and understanding. Dialogue in society is often a form of a culturological or religious-philosophical thought. If the interlocutors use moral and ethical, righteous postulates in the dialogue, profess the ideals of truth and good, then such a dialogue usually led to mutually beneficial success, and if everything went the other way, the mediation of the dialogue did not take place and testified, so to speak, to the dialogue of the deaf. Let's note that at that time Christianity, rejecting the division into "familiar ones" and "foreigners", proposes to establish class and ethnic equality: "... there is no 
Jew, no pagan, no slave, no free, no male or female persons because we are all together in Jesus Christ" (Galatians, 1983, p. 125).

Over time, the new intercultural basis for the mediation of dialogue on a Christian basis is formalized in the theological and historical teachings of Augustine. He was characterized by attempts to build a universal culture of mankind: God as the creator of culture "created one and only one man, to thereby arousing in him a desire for social unity and harmony" (Augustine, 1998).

From ancient times, particularly in the Middle Ages, mediation of dialogue has performed a predominantly moral function. A peculiar example is the interdisciplinary philosophical treatises of P. Abélard (1122). In them, he foresaw both the dialogue of confessions and the dialogue of cultures (Abélard, 1995). We can assume that the wellknown Christian principles of equality of peoples and tribes, which generally promoted the evolution of progress from the barbarism of paganism to Christianity, theoretically did not recognize the opposition "we-they". But, in practice, such a confrontation existed. Let's recall that the thesis "we" was interpreted as a standard, the goal of culture, "they" - as a pre-culture, which over time can become a culture. On the other hand, attempts to impose Christian values on the world community would resemble a monologue instead of a dialogue. One of the first to make a mediation attempt to combine the stunning features of different cultures was the Neapolitan philosopher G. Vico. He tried to defend the thesis of cultural autonomy (Lifshitz, 1994). However, in the XVIII century, when the idea of total cultural unity dominated society, the ideas of the philosopher did not gain recognition. It should be noted that at that time almost only work by Ch. L. de Montesquieu "About the Spirit of Laws" opposed the general European public opinion. The French judge emphasized that it is extremely difficult to change the nature of peoples: "it is better to change them through other customs, that is, through communication... the more peoples communicate, the easier it is for them to change their customs" (Montesquieu, 1955).

However, the most successful theory of mediation of dialogic forms of communication in modern times was the development of I. Kant, which he expressed in the theory of "hostile communication between people". To his opinion, a person can feel a person if he communicates with a person similar to him. (Kant, 1994). At the same time, we note that the communication program of the German philosopher was a kind of prerequisite for the concept of dialogue, which was developed by
G. W. F. Hegel. He interpreted the communication program based on the idea of a universal Mind. In this case, the philosopher interprets the idea of common and individual, inherent in each culture, original values. In general, his communication, dialogue, and mediation program were a kind of sprouts of rationalist culturological thought of the XIX century. (Hegel, 2006).

Other German philosophers were also interested in the mediation of dialogical relations: J. G. Fichte and F.W. Schelling. Later, L. A. von Feuerbach, based on the ideas of J. G. Fichte on the uniqueness and interdependence of "I" and "other" began to study the dialogue of the early XX century. (Feuerbach, 1995). For his part, J. G. Herder argued that the interaction of cultures contributes to the preservation of cultural diversity, and the isolation of cultures will lead to the destruction of culture. At the same time, to his opinion, changes should not concern the "core" of culture (Herder, 1959).

It is due to the active or passive civilizational dialogue of the peoples of different countries that modern cultures have been formed. After all, the dialogue of peoples and their cultures, as a rule, led to the emergence of new scientific paradigms. Thus, the beginning of dialogue in antiquity testified to the fact that the mythical consciousness changed to a philosophical-discursive, critical one. On the other hand, the dialogues of the Renaissance heralded the formation of a new type of consciousness.

And today there are many works in which the world is depicted as a mosaic set of civilizational cultural and historical types. We remind you that even in the era of Romanticism there was a search for a kind of ideal, which was based on mediation attempts to combine different cultures. And this was due to the desire to overcome the isolationism of cultures. Scientists of different nations and different cultures paid attention to the significant role of culture, mediation of dialogue of cultures, their psychology. Thus, the founder of experimental psychology W. Wundt interpreted culture as the basis of human self-development, linking it with the fundamental laws of psychology. After all, as it is well known, the development of culture is conditioned by the degree of evolution of collectivist psychology and the psychology of nations. The very prospect of dialogue between peoples mainly depends on the level of development of their psychology (Wundt, 2001).

In public scientific thought of the second half of the XIX century, the concept of culture is increasingly mentioned in the status of a 
scientific category. It already means not only and not such a high level of development of society, intersecting with the categories of "civilization", "social-economic formation". Let's note, by the way, that this concept is introduced by Karl Marx. According to him, the basis for the integration of cultures is rooted in economic ties and various forms of political unification of peoples. And yet the representatives of scientific thought of the world, having different ideas about culture, agree on one thing - the analysis of the communicative process shows that it has become the main foundation for the mediation of the dialogue of cultures.

The problems of dialogue, in particular in the field of culture, were touched upon by representatives of various scientific schools. Thus, in the XX century M. Buber, F. Gogarten, F. Rosenzweig, O. Rosenstock-Huessy, G. Cohen, F. Ebner, and others pointed out the complexity and multidimensionality of the dialogue. However, in the development of the theory of dialogue, the palm of victory is given to M. Buber (Buber, 1995). His main credo was the interpretation of being as a dialogue between God and man, man and the world. Dialogue, according to the scientist, is creative and saving when it happens thanks to God, his commandments of morality, and love. The principle of dialogue is considered to be the basis of the mentioned concept of $\mathrm{M}$. Buber. Man acquires his qualities, essence only through dialogue with his peers (Buber, 1995).

It is significant that until the 80 s of the $\mathrm{XX}$ century in society, in the intelligence of scientists, the assessment of the dialogue of cultures as a process that contributed to the synthesis of cultures prevailed. Since the 90 s of the XX century in the context of globalization, these tendencies and assessments are permeated by the recognition of the real diversity of the dialogue of civilizational cultural, and historical systems. At the same time, the interests and rights of peoples as ethnocultural communities come to the forefront. At the same time, liberal concepts were characterized by the dominance of the interests and rights of individuals. In general, as a broad civilizational-historical analysis of the genesis and formation of dialogue in general and culture, in particular, has shown, the processes of interaction between peoples and their cultures were much more complex and nonlinear. After all, no direct "pumping" of the achievements of a highly developed culture into a less developed one was observed. And building on such simplified postulates the mediation concept of international cooperation of cultures as a source of progress proved ineffective.
Problems of the genesis and evolution of dialogue in general and in the field of culture, in particular, have been considered by scientists in various fields of scientific knowledge. Thus, in the field of sociolinguistics, they were studied by L. V. Shcherba, L. P. Yakubynskyi, literary and philosophical hermeneutics - H. G. Gadamer, phenomenology - E. Husserl, M. Mamardashvili, fundamental ontology - M. Heidegger, literary studies and semiotics - S. S. Averintsev, M. M. Bakhtin, M. Lakshin, Y. M. Lotman, in the basics of communication - A. Moles, V. Borev and others. The interaction of cultures was studied by K. Levi-Strauss, S. Artanovskyi, S. Arutyunov, B. Yerasov, L. Ionin, M. Ikonnikov, and others. In addition, as it turned out, the communication of different cultures occurs as the subject intersections and, mainly, through language. For H. G. Gadamer, for example, dialogue is a kind of application of familiar and foreign (Gadamer, 1988).

The theory of dialogue found its further continuation in the XX century when in scientific views on culture, romanticism was finally supplanted by the all-encompassing process of the logic of thinking. Philosophical and cultural paradigms of that time were aimed at maintaining differences in the hierarchy and integration of cultures. Thus, K. Levi-Strauss noted: "world civilization can not be on a global scale other than a coalition of cultures, each of which retains its identity" (Levi-Strauss, 1985). At this time, humanity is absorbing the flow of global reciprocity. Historical experience has shown that culture stops developing if it does not participate in dialogues with other cultures. The "I - you" dialogue becomes universal.

At that time, the schools of cultures of philosophers were in the lead in the development of theoretical issues of cultural studies, who interpreted the concept of dialogue as a "way of culture being". Let's note that the scientists in the culture at the present stage of globalization have moved to the analysis of a new type of human existence in culture. At the end of the XXth century, culture is increasingly captivating human beings in all spheres of life. Mediation of intercultural dialogue becomes the basis of knowledge of peoples, their understanding, and interaction. "In the deep idea of a dialogue of cultures, a new culture of communication is formed. The thinking and being of another person is not only deep in each of us, but it is also different thinking, a different consciousness, internally urgent for our being" (Vostriakova, 1998, p. 80). 
Thus, it is only through the interaction of the worldviews of different peoples that intercultural civilizational connections take place. In this case, we are interested, first of all, in the problems of revealing the system of interaction of cultures of nations and peoples. At the same time, two types of interaction can be distinguished: first, interactions at the level of language, verbal, and, secondly, at the level of dialogue of various components of each culture, i.e. - external and indirect, complex internal direction.

It is characteristic that the mediation of the dialogue of cultures contains in the structure and at the same time is based on the imperatives "foreign" and "familiar". As we can see, the fruitful interaction of cultures in a dialogic mode determines the formation of a single field of common culture on a variety of semantic and internally present in different cultures frameworks. At the same time, the recognition of these features of each culture leads from monologue to dialogue mode of communication. That is, humanity is gradually moving towards the formation of a single cultural space in parallel with the preservation of the peculiarities of each national culture. Dialogue as a community of cultural interactions gradually forms their common values. As J. Ortega y Gasset emphasized, the dialogue, in this case, acquires a multilevel deep universal direction. He emphasized: "Dialogue is a dialogue only when it can take place as an endless unfolding and formation of ever new styles of every cultural phenomenon that enters into dialogue". In the process of a complex, multi-layered dialogue of cultures, universal values are being formed (Ortega y Gasset, 2000).

In the heart of dialogue as a mediator is usually the need to build relationships between peoples, the need for mutual assistance, and mutual enrichment. Mediation of intercultural dialogue, at the same time, is an objective necessity and a condition for the development of different cultures. During the dialogue of cultures, mutual understanding emerges, which promotes peaceful cooperation and mutual enrichment, both spiritual and material. Thus, the dialogue of cultures, which is based on tolerance and mutual understanding, makes it possible to preserve the identifying national characteristics of each of the cultures. It is this way of dialogue that contributes to the formation of universal cultural values in the civilization-globalization space, aimed at preserving the national and mental features of the culture of each nation.
Let us note that the dialogue of culturesis possible only if the peoples need it. At the same time, it is possible only in the case of mutual determination of their cultural codes, family mental characteristics. Only in the process of dialogue of cultures is possible mutual understanding, mutual recognition of deep national features of different cultures, which leads to spiritual mutual enrichment and the creation of a world cultural space and universal values of interacting cultures. It should be recalled that in this way the stumbling block for the mediating role of the dialogue of cultures of different nations and peoples is the contradiction between the processes of preserving national characteristics of cultures and the formation of universal cultural values. The peculiarity of the interaction of national cultures proves that without the recognition of each nation, ethnocultural existence, in general, is impossible. After all, the dialogue of cultures provides opportunities for a comparative analysis of the unique features of each culture, its specifics.

Mediation of the dialogue of cultures of the West and the East plays a dominant role in the formation of the world civilizational socio-cultural space in the conditions of globalization. It is the mediation of the dialogue of cultures that has acquired universal significance in modern conditions. Significantly, Ukraine plays a special role in this dialogue, as it is geographically a kind of bridgehead for the intersection of cultures of East and West, Europe and Asia. The process of intersection and synthesis of Eastern and Western cultural traditions has been going on for a long time. Such processes highlight the need for enhanced mediation of the dialogue of cultures of different peoples in Ukraine itself, which has had a positive impact on the formation of universal values. But they could not help but affect the very culture of Ukraine. And today's cultural globalization and civilization processes carry certain risks and threats to the existence of national, mental features of Ukrainian culture. Nevertheless, it should be recalled and emphasized that the mediation of intercultural dialogue is based primarily on the priorities of universal values. As you know, K. Levi-Strauss has always emphasized the need to preserve the diverse and unique features of national cultures. He emphasized that "an integral relationship with another culture kills the creative originality of both parties" (Levi-Strauss, 1994). After all, dialogue acts as an important methodological principle of understanding and cognition of culture. During the dialogue, the essential features of culture are revealed, the dialogue can be interpreted as an immanent component of the historical 
process, a universal principle that ensures the self-development of culture. It is as a result of the interaction of cultures that all historical and cultural values arose, the process of formation of language forms took place, and creative thought was transformed.

It is interesting to note that the level and degree of development of culture, the spirituality of society in general, and man in particular largely depends on the level and degree of satisfaction of functional and everyday human needs. The more and more fully these needs are met, the more demanding a person is to them and the more time and opportunities he has for spiritual renewal and growth. At the same time, the purely functional characteristics of a person's everyday needs lose their primary essence. The same food, clothing, housing, etc. become a kind of element of sociocultural self-expression in social practice.

Thus, as the purely material capabilities of man in society increase and change the standards of socio-cultural orientations, as well as the dynamics of human needs.

Dialogue of different cultures, as a rule, is a dialogue of different types of spirituality, different mentalities, different social systems. The presence of mediation of dialogue with non-European cultures, for example, presupposes the existence of certain knowledge and understanding of these cultures. According to M. Eliade: “...sooner or later the dialogue with "others" - representatives of traditional, Asian and "primitive" cultures should no longer begin in the current empirical and utilitarian language (which can express only social, economic, political, medical realities, etc.), but in the language of culture, which can express human realities and spiritual values. Such a dialogue is inevitable; it is inscribed in the fate of history. It would be tragic naivety to think that it can be conducted indefinitely on a mental level, as it is now" (Eliade, 1998).

According to S. Huntington, the semantic multicolor of cultures from the beginning presupposes their peculiar isolation and requires dialogue. According to his concept, local cultural isolation can be broken only through dialogue with another culture. Through the philosophy of interaction, the universal penetrates the dialogue of cultures, allowing each culture to contribute to the spiritual universal potential. This spiritual arsenal is a certain acquisition of all mankind and is the result of the interaction of peoples during the dialogue of their cultures. At the same time, the mediation function of dialogue is a kind of interethnic communication, which involves, on the one hand, the mutual enrichment of national cultures, and on the other - the preservation of their identity. Universal culture resembles a tree with many branches. And, as it has been already emphasized, the culture of a nation can develop only when universal culture progresses. That is why contributing to the prosperity of the national ethnic culture, it is necessary to take care of the development of a single and diverse universal culture. It is known that one or another national culture is unique and unique, and its contribution to the universal spiritual treasury is unique and unique. Without considering the degree and level of interrelationships of the cultures of the peoples of the world in the mode of dialogue, it is impossible to know and recognize the history of any culture (Huntington, 2003).

Thus the dialogue of cultures dominates in the process of evolution of cultures of different nations, different peoples. At the same time, the spiritual culture of each nation reflects the life of society, the inner world of man, the meaning of life itself. As we can see, the functioning of a man of earthly civilization in the globalized modern world is impossible without the interaction of cultures in a mode of dialogue. Isolation of a national culture leads to its decline. While the interrelationships of cultures contribute to the flourishing not only of their national culture but also of other cultures.

At the present stage, in the context of globalization and civilization transformations, the mediating role of intercultural dialogue has grown incredibly. Atthesametime, however, theconditions for intercultural dialogue have deteriorated significantly. There are a lot of problems in his path. And as the scientist, O. Gordienko noted: "The solution of these problems presupposes such globalization of interaction of cultures in space and time at which self-realization of all and each culture through the interaction of all with each and everyone with all others becomes reality. In this way, the mechanism of interaction of cultures is problematized" (Gordienko, 1998).

Thus, the dialogue of cultures was and is a kind of mediator that dominates the civilizational evolution of mankind. For a long time, for thousands of years, the process of mutual enrichment of national cultures was formed, which formed a unique mosaic of civilization. It should be noted that the process of interaction of intercultural dialogue is nonlinear and complex. After all, not all components of national culture can objectively contribute to the accumulation of cultural values. The process of dialogue of cultures is the more fruitful, the closer these cultures are 
in the family and mentally, especially it concerns art cultures, their components. When analyzing the problems of the formation and development of the mediating role of intercultural dialogue, it is important to remember that the latter cannot be assessed outside the dialogue of religions. After all, the Ukrainian Orthodox Church has been conducting an active dialogue with all people of goodwill for several decades. At the present stage, such a dialogue has been somewhat suspended. In the post-perestroika years, at the time of Ukraine's independence, radical-fundamentalist dogmas and the struggle of representatives of various denominations for the supremacy of their denomination led to a huge church split. As a result, the inter-Christian mediation dialogue turned out to be practically frozen, which harmed Ukraine's international prestige. Although the dialogue of cultures in a polyethnic and multireligious country is especially important for unity and power. The interaction of cultures in Ukraine is now largely political, which hinders not only the consolidation of society but also the enrichment of the country, its contribution to the world cultural treasury, in the struggle for peace.

As it was emphasized, at the present stage in the conditions of globalization and civilization development the role of mediation of dialogue of cultures has come to the forefront of earthly problems. The mutual influence of cultures, especially of the East and the West, has noticeably increased. For example, the philosophy and culture of the East with its idea of inner harmony significantly influenced the American industry, especially the cosmetics industry, food, and more. If not so long ago the interrelationships, the interaction of the culture of East and West were inconspicuous, today they are dominant. The dialogue of these cultures, their complementarity, and mutual enrichment have become so dense that they increasingly resemble the relationship of two inseparable principles - "yin" and "yang" (Yatsenko, 1999).

In addition, the mediation of intercultural dialogue is becoming a core in the foreign policy of different countries of the East and the West, increasingly filling the foreign policy of different countries with its culturological content. So, as it turns out, at the present stage in the age of civilizational globalization, a system of international dialogue of cultures is gradually being formed. It is difficult to overestimate the role of UNESCO in the formation of a dialogue of cultures in the international arena. It is known that the issue of dialogue between civilizations, cultures, and peoples is the basis of standard UNESCO activities. Evidence that the development of dialogue in the name of peace is the main mission of UNESCO can be considered the UN declaration in 2001 of the International Year of Dialogue between Civilizations, Cultures, and Peoples. After all, since 2001, numerous international conferences and high-level meetings have been held in the dialogue of cultures, and many important international initiatives organized by UNESCO in various countries and regions have been introduced. All this was reflected in resolutions, declarations, programs, and publications and contributed to the spread of the mediating role of intercultural dialogue. At the same time, UNESCO and its organizations scattered around the world have done much to recognize and preserve the world's cultural heritage, which has helped to strengthen the relationship between peoples and cultures of different regions of the world (Dialogue of Cultures, Peoples, Civilizations).

Today, in the context of globalization, the dialogue of cultures between the peoples of the world is more important than ever. Mankind has faced an abyss of crisis, unstable situations, it has become more vulnerable. That is why people want international cultural exchange and mutual understanding in the name of peace and harmony. And not for nothing in 2001 at the General Conference of UNESCO a resolution was adopted calling for "international cooperation to prevent and eradicate terrorist attacks". It also confirms the need for dialogue based on the idea of the unity of mankind, common values for all people, recognition of cultural diversity (Dialogue of cultures, peoples, civilizations). At the UN World Summit in September 2005, the Heads of State and Government undertook to develop a dialogue between civilizations and to strengthen the culture of peace at the local, national, regional, and international levels. At the same time, UNESCO was to organize this work. The implementation of these and other challenges of the world community has contributed to the spread of the mediating role of cultural dialogue in the world.

Let's note that after the onset of the global economic crisis, the mediating role of intercultural dialogue has grown significantly. Work under the auspices of UNESCO has intensified in line with the spread of dialogue between the cultures of different peoples and the processes of upholding the principles of freedom of speech and respect for cultural and religious symbols. It is significant that today UNESCO member states no longer care so much about the slogans of dialogue between 
cultures and civilizations, but strive for real results, concrete approaches, and practical actions in all areas of UNESCO's activities: culture, education, science, social communication, and information, etc.

Surprisingly, many UNESCO programs in the field of intercultural dialogue are based on the concept of so-called "paths". History knows many such ways: "The Great Silk Road", "Slave Way", "Iron Way" in Africa, and others. Historical experience shows that they all contributed to cultural dialogue through culture and the arts, trade, and migration. In addition, these processes have been accelerated by the globalization of civilization. On the one hand, the processes of globalization and civilization have intensified the cultural exchange between peoples, their dialogue, on the other hand, globalization has led to the threat of the existence of identifying national characteristics of different cultures and different mentalities. The problem of "familiar and foreign" in the age of globalization, especially in the field of culture, has become somewhat acute. And, again, only intercultural dialogue can contribute to the strengthening of social cohesion and sustainable development of mankind.

In light of this, the problem of the role of religious dialogue has become especially acute, on which the fate of intercultural dialogue in general largely depends.

That is why in today's world, against the background of growing intra-religious and interreligious conflicts, UNESCO programs are paying more and more attention to issues of interfaith dialogue, dialogue between different religions, and spiritual traditions. Such conflicts usually arise against the background of misunderstanding or rejection of other cultures or traditions. That is why this UNESCO program is regarded as an important aspect of intercultural dialogue. The program focuses on the interaction and interaction of different religions, spiritual and humanistic values, as well as the need for deeper knowledge about other cultures and religions. After a series of conferences, international high-level meetings, interfaith conferences organized by UNESCO, it was planned to establish several UNESCO chairs in different countries. These departments aimed to create a comprehensive system that would include research, training, information, and documentation activities in the field. At the same time, these departments were to promote humanitarian and cultural dialogue between themselves and the higher education institutions at which they were established.
In addition, to promote cooperation through the mediation of dialogue of cultures and civilizations, UNESCO has outlined such kind of program:

- forming a base of spiritual priorities acceptable to most peoples;

- creation of appropriate cooperation programs at the regional and subregional levels, their practical orientation;

- uniting under the auspices of UNESCO around this program not only representatives of government agencies but also all interested organizations and segments of the population, especially - young people and women;

- involvement in the implementation of cultural and dialogue programs of religious organizations;

- studying the role of women in cultural dialogue and women's empowerment.

The commitments made in June 2005 in Rabat played an important role in the implementation of this program. Many practical measures have been taken in this direction, in accordance with the competence of UNESCO, and all the organizations that took part in the Rabat conference have expressed their determination to continue on the planned path of dialogue of cultures (Dialogue of cultures, peoples, civilizations).

As it was already noted, the era of globalization has posed to the world civilization a lot of cardinal, crucial issues, the solution of which urgently requires an international dialogue of cultures. In this regard, the problems of openness to dialogue between the peoples of the world and their mutual understanding in the modern world are becoming crucial. And if before there was enough mutual understanding between peoples, their goodwill, today there is a need for cross-cultural approaches, in which there is an understanding of the cultures of other peoples: "awareness of differences in ideas, customs, cultural traditions inherent in different peoples, the ability to see common and different between cultures and look at the culture of their community through the eyes of other peoples" (Lapshin, 1999, p. 47). On the other hand, the ability to understand the culture of another people requires a thorough knowledge of national culture, i.e. the success of cultural dialogue at the present stage of development of the world community is possible and successful only if there is deep knowledge of their national culture and recognition of other peoples.

As historical experience shows, mediation of dialogue of cultures of different peoples largely depends not so much or not only on formal contacts of officials but on informal contacts of prominent 
leaders of nations, creative, scientific, and artistic groups, and their representatives.

Conclusions. Thus, the mediating role of intercultural dialogue at the present stage is extremely necessary not only for the preservation of peace but also for mutual enrichment, mutual development, mutual exchange of experience, both within certain cultures and on the scale of global culture. It can be argued that mediation of intercultural dialogue acts as a guarantee of selfpreservation of the world community. And as we have seen, the dialogue of cultures in the modern world is a complex process and often requires delicacy in its implementation. After all, it is necessary to satisfy the interests and needs of each of the parties to the dialogue.

Thus, with a certain degree of conventionality, it can be argued that at the heart of the evolution of the current model of culture, both national and world, is the mediating role of the dialogue of national cultures themselves. At the same time, mediation of intercultural dialogue is a way to remove contradictions both between different poles of thought in the closed culturological environments of national systems and between cultures and societies of different peoples of the world. At the same time, the mediation of the dialogue of cultures, in our deep conviction, is the key to world cultural synthesis and sustainable development of human civilization.

To sum up, we can say that the analysis of the emergence and formation of mediation phenomena of dialogue as such and in the field of culture, in particular, shows the direct dependence of the effectiveness of sustainable development of the earth community on the level and scale of its foundation in the age of civilizational globalization. The leading mediating role of the organizer of these processes in the evolution of intercultural dialogue on a global scale should belong to global centers and, above all, to UNESCO and its institutions. It is their activity that has become the coordinator in the field of the evolution of the dialogue of cultures, in the establishment of stable culturological relations between regions, continents, different nations, and peoples of the world.

\section{References}

Abeliar, P. (1995). Theological treatises. Progress: Gnozis. [In Russian].

Arefieva, A. Yu. (2019). Dialogue and dispersion as paradigms of cultural globalization. Ukrainska kultura: mynule, suchasne, shliakhy rozvytku. Kulturolohiia: collection of scientific works. Issue 31, 103-107. [In Ukrainian].
Averintsev, S. (1989). The image of antiquity in the Western European culture of the XX century. Some remarks. S. S. Averintsev (Ed.). Novoev sovremennoy klassicheskoy filologii. Nauka. [In Russian].

Avgustin, A. (1998). Creations. (Vol. 2). Teologicheskie traktaty. Aleteyya; UTsIMM-Press. [In Russian].

Buber, M. (1995). Two Images of Faith: Collection. Respublika. [In Russian].

Chernets, M. O. (2015). Cultural mission of intercultural dialogue in the context of the European Capital of Culture initiative. Mizhnarodnyi visnyk: Kulturolohiia. Filolohiia. Muzykoznavstvo. Issue 2, 104-107. [In Ukrainian].

Dialog kultur, narodov, tsivilizatsiy. http://www.unesco. ru/files/docs/ [In Russian].

Dynikova, L. Sh. (2014). Dialogue as a way of learning culture. Kulturolohiia. Filolohiia. Muzykoznavstvo: international bulletin, collection of scientific works. Issue 2 (1), 73-79. National Academy of Management of Culture and Arts, A. V. Nezhdanova Odesa National Music Academy. Milenium. [In Ukrainian].

Eliade, M. (1998). Mephistopheles and the androgyne. E. V. Baevskaia, O. V. Davtian (Trans.). Universitetskaya kniga. [In Russian].

Epistle to Galatians. (1983). Bible. Books of the Holy Scriptures of the Old and New Testaments. [In Russian].

Feierbakh, L. (1995). Works: in 2 volumes. Nauka. [In Russian].

Gadamer, H. G. (Trans.). (1988). Truth and Method. Fundamentals of Philosophical Hermeneutics. Progress. [In Russian].

Hegel, G. V. F. (2006). System of Sciences. (P. 1). Fenomenologiya dukha. Nauka. [In Russian].

Herder, I. (1959). Selected works. Goslitizdat. Leningradskoe otdelenie. [In Russian].

Gordiienko, A. A. (1998). Anthropological and cultural preconditions for the co-evolution of man and nature: a philosophical and anthropological model of co-evolutionary development. TsSA. [In Russian].

Herashchenko, M. (2018). Genesis and the development of mediation in a cross-cultural environment. Kultura i suchasnist, 1, 239-243. [In English].

Kant, I. (1994). Criticism of judgment. Iskusstvo. [In Russian].

Hantington, S. (2003). Third wave: Democratization at the end of the XX century. Rossiyskaya politicheskaya entsiklopediya. [In Russian].

Korniienko, V. V. (2010). European intercultural dialogue in the context of the formation of a single cultural space. Kultura Ukrainy: collection of scientific works. Issue 29, 5-15. Kharkiv State Academy of Culture. [In Ukrainian].

Kozak, A. (2013). Intercultural communication in the context of intercultural dialogue. Naukovi zapysky. Seriia: Filolohichni nauky: collection of scientific works. Volodymyr Vynnychenko Kirovohrad 
State Pedagogical University. Issue 118, 106-110. [In Ukrainian].

Lapshin, A. G. (1999). International Cooperation in Humanities Education: A Cross-Cultural Literacy Perspective. Krosskulturnyi dialog: komparativnye issledovaniya $v$ pedagogike i psikhologii: collection of articles, p. 45-50. [In Russian].

Lévi-Strauss, K. (1985). Structural anthropology. V. V. Ivanov (Trans.). Nauka. [In Russian].

Lévi-Strauss, K. (1994). Primitive thinking. Respublika. [In Russian].

Lifshits, M. (1994). Giambattista Vico. Foundations of a New Science of the General Nature of Nations, p. 3-19. [In Russian].

Mezhuev, V. M. (2011). Dialogue as a way of intercultural communication in the modern world. Voprosy filosofii, 9, 65-73. [In Russian].

Mitkina, O. (2013). Review of approaches to the study of intercultural dialogue and processes of interaction of cultures. Mizhnarodni zviazky Ukrainy: naukovi poshuky i znakhidky, 22, 324-336. [In Ukrainian].

Montesquieu, Ch. L. (1955). Selected works. Gospolitizdat. [In Russian].

Nikitin, V. (2000, February, 3-9). From a dialogue of confessions to a dialogue of cultures. Russkaya mysl', p. 26. [In Russian].

Ortega y Gasset, J. (2000). Selected Works. Infra-M: Ves Mir. [In Russian].

Rogochaia, G. P. (2018). Cross-cultural dialogue and mediation of cross-cultural conflicts. Kontury budushchego $v$ kontekste mirovogo kul'turnogo razvitiya: XVIII Mezhdunarodnye Likhachevskie nauchnye chteniya, 17-19 maya 2018. Saint Petersburg State University of Trade Unions, 443454. [In Russian].

Saiko, E. V. (1990). On the nature and space of «action». Sotsiokulturnoe prostranstvo dialoga, p. 10. [In Russian].

Shcherbyna, V. M. (2011). Formation of dialogue of cultures in the conditions of societies of the beginning of the XXI century. Kulturolohichna dumka, 4, 13-18. [In Ukrainian].

Sinitsyna, A. O. (2017). Cultural mediation and its forms in pedagogical science and practice in France. Vestnik Assotsiatsii vuzov turizma i servisa, Vol. 11, № 1, 67-76. [In Russian].

Stepyko, K. M. (2014). Condition and tendencies in the formation of dialogue in the Ukrainian culture. Hileia: scientific bulletin, 84, 479-484. [In Ukrainian].

Vostriakova, Yu. V. (1998). Problems of cognition in the dialogue space of modern culture. Filosofskometodologicheskie problemy nauki $i$ tekhniki. [In Russian].

Wundt, V.(2001). Problems of the psychology of peoples. [In Russian].

Vysotskyi,A.(2015). Clash of cultures - between conflict and dialogue of cultures. Mizhnarodnyi naukovyi forum: sotsiolohiia, psykholohiia, pedahohika, menedzhment, 17, 30-41. [In Ukrainian].

Yasynovskyi, I. H. (2014). Historical aspect of development of the institute of mediation and modern tendencies of its development. Naukovyi visnyk Mizhnarodnoho humanitarnoho universytetu. Seriia: Yurysprudentsiia. Issue 10-2 (1), 31-33. [In Ukrainian].

Yatsenko, E. (1999). East and West: Interaction of Cultures. Kultura $v$ sovremennom mire: opyt, problemy, resheniya, 1, 32-37. [In Russian].

Yevtukh, V. (2009). Intercultural dialogue: an effective construct of integrative development of polyethnic societies. Politychnyi menedzhment, 3, 3-13; 4, 1427. [In Ukrainian].

Надійшла до редколегії 03.06.2021 